\title{
Management of the Center of Educational and Training Cruise at Malahayati Aceh Indonesia
}

\author{
Rispa Saeful Mu'tamar \\ Department of Educational Administration \\ Syiah Kuala University, Indonesia \\ profcut@unsyiah.ac.id
}

\author{
Cut Zahri Harun \\ Department of Educational Administration \\ Syiah Kuala University, Indonesia \\ profcut@unsyiah.ac.id
}

\author{
Sakdiah Ibrahim \\ Department of Educational Administration \\ Syiah Kuala University, Indonesia \\ profcut@unsyiah.ac.id
}

\begin{abstract}
The purpose of this research is to find out the arrangement of BP2IP Malahayati Aceh which is good in empowering educators, education staff and all academics so that the education and training activities in shipping at BP2IP Malahayati Aceh can run smoothly. This study uses a qualitative approach. Data collection techniques are: interview, observation, and documentation study. Data analysis techniques with data reduction, data display, drawing conclusions and verification. The subjects of this study were the Head of BP2IP Malahayati Aceh, the Head of the Finance and General Sub-Section, the Section Head of the Training and Cooperation Section of the Training Center, the Head of Education and Training Facilities Section, Instructor I BP2IP Malahayati Aceh and the Instructor II BP2IP Malahayati Aceh, there were 6 people. The results of the study are: (1) planning for the implementation of shipping science and education that is structured by BP2IP Malahayati Aceh has been well arranged; (2) the implementation of the BP2IP Malahayati Aceh plan in regulating the organization and empowering all components of education in conducting shipping education and training in BP2IP Malahayati Aceh has been carried out to the maximum in accordance with what has been prepared previously, although there are several obstacles but can still be overcome; and (3) the system for controlling the delivery of shipping science education and training carried out by BP2IP Malahayati Aceh has been carried out well, in accordance with predetermined standards of supervision procedures.
\end{abstract}

Keywords: management, BP2IP Malahayati Aceh

\section{INTRODUCTION}

Education is a sector that greatly determines the quality of a nation. The failure of education has implications for the failure of a nation; the success of education also automatically brings the success of a nation. In the world of education, should pay attention to the elements of education, which include: students, educators, management, facilities and infrastructure and stakeholders. Assets needed in education are human resources that are quality. Quality resources can be from students, the community, as well as from educators.

The implementation of an education has a function, including: initiation, innovation, and conservation. Initiation is an educational function to initiate a change. Innovation is a media for achieving the change. Conservation has function to safeguard basic values; therefore, to improve the life of a nation, it must begin the arrangement of all aspects of education. One aspect in question is education management. In Law Number 20 of 2003 concerning the National Education System (Sisdiknas), especially those set out in article 3, aims to develop the potential of students to become faithful and fearful people of God Almighty, noble, knowledgeable, capable, creative independent and become a democratic and responsible citizen.

It was also explained in Law Number 20 of 2003 concerning the National Education System (National Education System) the fifth part about non- formal education which aims to develop the potential of students with an emphasis on mastering functional knowledge and skills and developing professional attitudes and personalities. Balai Pendidikan dan Pelatihan Ilmu Pelayaran (BP2IP) Malahayati Aceh is a maritime education and training institution for the Ministry of Transportation, Human Resources Development Agency (BPSDM) of Transportation which aims to provide sea transportation human resources.

Based on the description above, the writer would like to do research with the title "Management of Balai Pendidikan dan Pelatihan Ilmu Pelayaran (BP2IP) Malahayati Aceh". The purpose of this research is to find out the arrangement of BP2IP Malahayati Aceh which is good in empowering educators, education staff and all academics so that the education and training activities in shipping at BP2IP Malahayati Aceh can run smoothly.

\section{METHODS}

This research use descriptive qualitative approach. In connection with this problem Surachmad (2014) said in general, descriptive forms of inquiry are telling and interpreting existing data, about situations that are experienced, attitudes that appear or about an ongoing process. The characteristics of descriptive research, namely (1) Focusing on solving the problems that exist in the present, on actual problems, and (2) 
The data collected is initially compiled, explained and then analyzed. Descriptive research does not intend to test hypotheses. Qualitative research is not just a data collection technique, but is a way of approaching empirical data.

Qualitative research according to Arikunto (2014) is research that does not use numbers in collecting data and in giving an interpretation of the results. A response, especially in empirical sciences, generally aims to find, develop or test the truth of knowledge. According to Hadi (2016) finding means trying to get something to fill a void or lack, developing means expanding and digging deeper into what is already true or doubtful, so that the results of the research are countable works of science. Based on the quote, the phenomenon in this study is about: Management of Balai Pendidikan dan Pelatihan Ilmu Pelayaran Malahayati Aceh

\section{RESULT}

Educational Planning and Maritime Training Arranged by BP2IP Malahayati Aceh BP2IP Malahayati Aceh currently prepares Lesson Plan using Curriculum. Readiness for the complete set of learning tools in BP2IP Malahayati Aceh is now sufficient. Submission of learning material that will be delivered at BP2IP Malahayati Aceh has been adjusted to the Lesson Plan that has been prepared. The preparation of the teaching schedule at BP2IP Malahayati Aceh was compiled by the Curriculum Field Waka that had been adapted to Curriculum standards.

1. Implementation of BP2IP Plan for Malahayati Aceh in Managing Organizations and Empowering All Components of Education in Organizing Maritime Education and Training at BP2IP Malahayati Aceh

The Answer Results Interview with Head of BP2IP Malahayati Aceh, the Head of the Finance and General Sub-Section, the Section Head of the Training and Cooperation Section of the Training Center, Head of Education and Training Facilities Section, Instructor I BP2IP Malahayati Aceh and Instructor II BP2IP Malahayati Aceh, the number of 6 people obtained answers: BP2IP Malahayati Aceh conducts annual program preparation adapted to the curriculum.

BP2IP Malahayati Aceh Institution organizes semester programs appropriate to the curriculum. According to BP2IP Malahayati Aceh, the purpose of drafting the Lesson Plan is to limit and adjust the targets and its to be achieved so that they can be implemented as expected. The BP2IP Malahayati Aceh institution performs the division of tasks in accordance with what has been arranged by the Waka Curriculum. The constraints faced by the BP2IP Malahayati Aceh Institution during teaching were the lack of concern for the implementation of the learning process, sometimes underestimated by some parties.

2. System for Controlling the Implementation of Education and Maritime Training Implemented by BP2IP Malahayati Aceh
The supervision carried out in BP2IP Malahayati Aceh is in accordance with their respective functions. The last stage in the learning supervision process is the feedback meeting stage. Repeat meetings are carried out immediately after carrying out teaching observations, with an analysis of the results of supervision. The main objective of this feedback meeting was to follow up on what was seen by the supervisor, as an observer, towards the teaching and learning process.

\section{DISCUSSION}

BP2IP Malahayati Aceh was inaugurated on November 23, 2011 by the Minister of Transportation and began conducting shipping and education training activities in 2013 by opening a Level of IV (DP-IV) Sailor Training program and Basic Safety Training (BST) Proficiency Training Program (DKP), Advance Fire Fighting (AFF), Medical First Aid (MFA), and Medical Care (MC). In its development, BP2IP Malahayati Aceh experienced a very rapid development where in 2017, BP2IP Malahayati Aceh had three formation seafarers training programs, namely the Rating, DP-III and DP-IV Forming Programs, four improvement programs for seafarers training namely DP-III Improvement, DP-IV Improvement, DP-V Improvement, and Able Seafarers.

Education in Indonesia, both formal and nonformal education are expected to produce qualified graduates who are recognized at national, regional and international levels and the graduates have the knowledge, skills and personal character and reliable character. Without producing qualified graduates, education programs are not an investment in human resources, but only a waste both in terms of cost, energy, time, and will cause various social problems. The aim of the expected education is to create quality education outcomes in accordance with the expectations of various parties. In this case, education management has a very important role in realizing educational goals.

Good management in the world of education in Indonesia is expected by all Indonesians. Management is an art for managing things, whether people or work. Understanding management is a process carried out to achieve an organization's goals by working in teams. In an application, management has subjects and objects. The subject is the person who regulates while the object is regulated. According to Terry (2013) management is a process or framework, which involves the guidance or direction of a group of people towards organizational goals or real intentions.

The management carried out in managing each component will have an impact on the success or failure of education and learning in schools. These conditions indicate that the success of a school in achieving its goals and realizing its vision and mission lies in how the principal's management and leadership, especially in mobilizing and empowering various components of the school. In the process of dynamic quality interaction between heads, teachers, administrative staff, and students play a very important role, especially in adjusting various school activities 
with the demands of globalization, changes in society, the development of science and technology, as well as the demands of the situation, conditions and environment.

All of them are very demanding of competence and professionalism to enable the creation of dynamic quality interactions. From this explanation, BP2IP Malahayati Aceh led by the head, must be able to empower educators and education personnel as well as the entire academic community of BP2IP Malahayati Aceh to be able to realize a quality, smooth and productive learning process. These conditions are part of the management implementation. Having good and regular management, BP2IP Malahayati Aceh will be able to carry out its duties more professionally. Professional work will be able to handle the challenges that will be faced, and can achieve its goals.

The implementation of the maritime education and training at BP2IP Malahayati Aceh, in its implementation there are several problems that occur especially in the implementation of learning activities such as, the instructor does not teach in the classroom so that many classes are empty, the monitoring team does not check the class at all times so the instructor's recapitulation is not appropriate, the laboratory and simulators are rarely used properly for learning activities because instructors tend to provide material only in class, some instructors do not teach in class but only provide assignments, absences and teaching evidence instructors in the class are never filled in each subject so that they are considered not teaching so that it becomes an obstacle in the learning process for cadets of BP2IP Malahayati Aceh and it was feared that cadets could not understand shipping well so that the competence of graduates of the BP2IP cadets in Malahayati Aceh was not in line with what was expected.

\section{CONCLUSION}

Planning for Maritime education and training that organized by BP2IP Malahayati Aceh has been well arranged. The implementation of the BP2IP Malahayati Aceh plan in regulating the organization and empowering all components of education in carrying out shipping science training and training at BP2IP Malahayati Aceh has been carried out optimally in accordance with what has been prepared previously, although there are some obstacles but can still be overcome. The controlling system for the implementation of Maritime education and training which is carried out by BP2IP Malahayati Aceh has been carried out well, in accordance with predetermined standards of supervision procedures.

\section{REFERENCE}

[1] Arikunto, S. 2014. Basics of Educational Evaluation. Jakarta: Earth Literacy.

[2] Hadi, S. 2016. Basic Field Study Research Methodology Problems of Experimental Design and Analysis Consistency. Surabaya: Airlangga University.

[3] Surakhmad, W. 2014. Introduction to Basic Scientific Research. Bandung: PT Tarsito.
[4] Terry, R. G. 2013. Fundamentals of Management. Jakarta: Earth Literacy.

[5] Indonesian Government Act. 2003. Law No. 20 of 2003 Concerning the National Education System. Jakarta: Ministry of Education and Culture. 